\title{
Effects of Perennial Ryegrass Cultivars on Milk Yield and Nitrogen Utilization in Grazing Dairy Cows
}

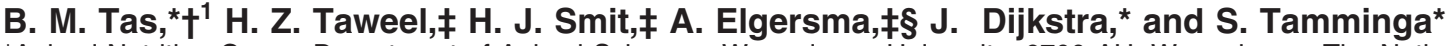 \\ *Animal Nutrition Group, Department of Animal Sciences, Wageningen University, $6700 \mathrm{AH}$, Wageningen, The Netherlands \\ †Institute of Animal Nutrition and Physiology, Christian-Albrechts-University, Kiel, Germany \\ $\ddagger$ Crop and Weed Ecology Group, Department of Plant Sciences, Wageningen University, Wageningen, The Netherlands \\ $\S$ Department of Plant Production, Faculty of Bioscience Engineering, Ghent University, Belgium
}

\begin{abstract}
The effects of 4 diploid perennial ryegrass cultivars that differed in water-soluble carbohydrate (WSC) concentrations on milk yield and nitrogen $(\mathrm{N})$ utilization in dairy cows were evaluated in a 2-yr grazing experiment. Twelve lactating dairy cows were assigned to 1 cultivar for a 2 -wk period in a $4 \times 4$ Latin square design with 3 replicates. Each year, the experiment lasted 8 wk. Swards were in a vegetative stage throughout the experiment. Herbage constituents were determined, and DM intake was estimated with the $n$-alkane technique. Nitrogen utilization was calculated as $\mathrm{N}$ excreted in milk divided by $\mathrm{N}$ intake, assuming a zero $\mathrm{N}$ retention. Two cultivars had consistently higher WSC concentrations and slightly lower neutral detergent fiber concentrations than the other 2 cultivars. The ranking of the cultivars in chemical composition traits in both years was rather consistent. Cows grazing the cultivar with the lowest concentration of WSC had the lowest herbage $\mathrm{DM}$ intake, $\mathrm{N}$ intake, milk yield, and milk $\mathrm{N}$ yield in 2002 , but with a similar difference in WSC concentration, no differences among cultivars were found in 2003. In both years, milk urea $\mathrm{N}$ concentration was slightly higher for cows grazing the cultivar with the lowest WSC concentration, although it was significant only in 2003. Nitrogen utilization (N milk:N intake, g/g) varied between 0.241 and 0.246 in 2002 and between 0.190 and 0.209 in 2003, and in both years there was no effect of cultivar. At relatively high $\mathrm{N}$ concentrations in grass and only small differences among cultivars in neutral detergent fiber concentrations, cultivars with an elevated WSC concentration did not increase $\mathrm{N}$ utilization in grazing dairy cows.
\end{abstract}

Key words: perennial ryegrass, cultivar, grazing, nitrogen utilization

Received January 29, 2006.

Accepted May 4, 2006.

${ }^{1}$ Corresponding author: tas@aninut.uni-kiel.de

\section{INTRODUCTION}

In temperate areas of the world, high-quality forages, notably fresh grass, are among the cheaper components in dairy diets. Grazing systems should aim at maximizing herbage DMI while maintaining a high quality and quantity of the sward over the grazing season (Peyraud et al., 2004). Dairy cows with a high proportion of forages in their diet (Veerkamp et al., 1994), or those grazing intensively managed grassland (Kolver and Muller, 1998; Peyraud et al., 2004), have a lower milk yield (MY) than cows fed concentrate-supplemented diets. The lower MY could be attributed partly to a lower DMI and partly to an imbalance among absorbed nutrients (Kolver and Muller, 1998). Another aim of modern grassland-based dairy farming is to improve the low nitrogen $(\mathrm{N})$ utilization and to reduce $\mathrm{N}$ losses to the environment. Intensive use of fertilizer $\mathrm{N}$ and selection by the cows of young and leafy grass not only result in the intake of highly digestible herbage with a relatively high energy concentration, but also with a high CP concentration. At a high CP concentration, the supply of $\mathrm{N}$ often exceeds the supply of energy from carbohydrates required for microbial growth in the rumen. Almost $80 \%$ of this excess $\mathrm{N}$ is excreted in urine (van Vuuren, 1993).

Differences among perennial ryegrass cultivars in their concentrations of water-soluble carbohydrates (WSC) were consistent and heritable (Humphreys, 1989). A comparison of 2 ryegrass cultivars showed an increased digestible DMI, MY, and N utilization in the cultivar with an increased WSC concentration (Miller et al., 2001). Miller et al. (2001) speculated that the efficiency of microbial protein synthesis was increased because of the higher WSC concentration, and this was confirmed by infusing sugars into perennial ryegrass in an in vitro fermentation system (Lee et al., 2003), but could not be demonstrated in vivo in the rumen of steers (Lee et al., 2002). However, in the studies of Miller et al. (2001) and Lee et al. (2002), the CP concentration in grass was low (92 to $107 \mathrm{~g} / \mathrm{kg}$ of DM) and the $\mathrm{NDF}$ concentration was high (>540 $\mathrm{g} / \mathrm{kg}$ of DM) because 
of a relatively long regrowth period of $6 \mathrm{wk}$ and low $\mathrm{N}$ fertilization levels, and this may have influenced their results. In a 2-yr stall-feeding experiment, cultivars with an elevated WSC concentration did not increase the DMI and MY (Tas et al., 2005), nor was the N utilization in dairy cows improved (Taweel et al., 2005; Tas et al., 2006). The aim of this study was to evaluate the effects of 4 diploid perennial ryegrass cultivars, differing in WSC concentration, on MY and N utilization in grazing dairy cows.

\section{MATERIALS AND METHODS}

\section{Cows, Cultivars, and Experimental Design}

In July and August of 2002 and 2003, 2 grazing experiments were conducted with 12 dairy cows. Both experiments lasted $8 \mathrm{wk}$, divided in four 2 -wk periods. For $3 \mathrm{wk}$ before the experiments started, cows grazed a perennial ryegrass sward. In 2002 , the cows were in their second to fourth lactation, $67 \pm 4.2 \mathrm{DIM}$ at the start of the experiment, BW was $528 \pm 7.1 \mathrm{~kg}$, and MY was $32.7 \pm 0.9 \mathrm{~kg} / \mathrm{d}$ in the adaptation period. The cows used in 2003 were in their second to fifth lactation, 79 $\pm 3.7 \mathrm{DIM}$ at the start of the experiment, BW was 549 $\pm 6.7 \mathrm{~kg}$, and MY was $30.7 \pm 0.9 \mathrm{~kg} / \mathrm{d}$ in the adaptation period.

The cows grazed 4 diploid perennial ryegrass cultivars (cultivars 1 to 4 ): 2 intermediate-heading types (May 27; Abergold and Agri) and 2 late-heading types (June 10; Barezane and Barnhem). Two cultivars (1 and 4) had a higher WSC concentration than the other 2 cultivars ( 2 and 3 ) in a stall-feeding experiment conducted in 2000 and 2001 (Tas et al., 2005). The 4 cultivars were sown on 2 paddocks in Wageningen, The Netherlands, according to a randomized complete block design with 3 replicates. At all times, the cutting and fertilizing regimen was similar for all cultivars. Prior to the experiment and after each grazing event, the sward was cut at $6 \mathrm{~cm}$ above ground level and herbage was removed. Pasture management aimed at an herbage mass at $4 \mathrm{~cm}$ above ground level of $2,000 \mathrm{~kg}$ of DM/ ha. Herbage mass was estimated by cutting strips of at least $5 \%$ of the total area with a mowing machine (Agria 3200; Agria-Werke, Möckmuhl, Germany) at a stubble height of $4 \mathrm{~cm}$. Grass was collected and weighed, and duplicate samples were oven-dried at $70^{\circ} \mathrm{C}$ for 24 h. Grass morphology was determined by hand-separating a plucked sample into stem, leaf blade, pseudostem, and dead material. Initially, the fertilization level was $55 \mathrm{~kg}$ of N/ha per cut. However, during the first 2 periods in 2002, the grass growth was lower than expected; therefore, the fertilization level was increased to $75 \mathrm{~kg}$ of N/ha per cut in the last 2 periods in 2002 and in
2003. The regrowth period was approximately $23 \mathrm{~d}$ in 2002 and $29 \mathrm{~d}$ in 2003. In 2003, more regrowth days were necessary owing to retarded grass growth because of warm and dry weather conditions. Each paddock was therefore irrigated 6 times with $15 \mathrm{~mm}$ in July and August. See Smit et al. (2005a) for a detailed description of pasture management.

Each paddock was divided into 12 strips of $22 \times 84$ $\mathrm{m}$, and each strip was sown with one of the 4 cultivars. Mobile fences were established every $6 \mathrm{~m}$ across the 12 strips, to obtain daily plots of $132 \mathrm{~m}^{2}$ per cow. With an herbage mass of approximately $2,000 \mathrm{~kg}$ of DM/ha, this would result in an herbage allowance of $25 \mathrm{~kg}$ of DM/ cow per d, enough to ensure an unrestricted access to fresh grass. A strip-grazing system was applied, and each plot was grazed by a cow for $24 \mathrm{~h}$. Cows were moved at $1200 \mathrm{~h}$ to a new plot. Cows grazed in periods 1 and 3 on one paddock and in periods 2 and 4 on the other paddock. All cows were assigned for a 2 -wk period to 1 cultivar in a $4 \times 4$ Latin square design.

Cows were milked twice a day at 0600 and $1600 \mathrm{~h}$, and diets were supplemented with $2.7 \mathrm{~kg}$ of DM/d of concentrate feed in 2 equal portions at milking. Dotriacontane $\left(\mathrm{C}_{32}\right) n$-alkane marker was added to the concentrate feed to estimate DMI (Mayes et al., 1986; Smit et al., 2005a,b). The MY of each cows was recorded at each milking.

\section{Sampling, Analyses, and Measurements}

On d 8 to 13 in each period, herbage samples were plucked by hand at 0700,1330 , and $2000 \mathrm{~h}$. After cows were moved to a new plot, all dung patches on each plot that were excreted after $24 \mathrm{~h}$ of grazing were sampled and stored at $-20^{\circ} \mathrm{C}$. Sample handling and chemical analyses of herbage, feces, and concentrate feed are described by Smit et al. (2005a).

Two composite milk samples in the evening and consecutive morning (1:1, vol:vol) were taken from each cow. One sample was analyzed for milk fat and protein concentration by near-infrared reflectance spectroscopy according to ISO Standard 9622 (ISO, 1999), and the other for MUN concentration with the $\mathrm{pH}$ difference method according to ISO Standard 14637 (ISO, 2004); Melkcontrolestation, Zutphen, The Netherlands).

\section{Calculations and Statistical Analyses}

The efficiency of $\mathrm{N}$ utilization was calculated as $\mathrm{N}$ excretion in milk (protein yield/6.38) divided by total $\mathrm{N}$ intake ([N concentration in grass $(\mathrm{N}=\mathrm{CP} / 6.25) \times$ herbage DMI] + concentrate feed $\mathrm{N}$ intake), assuming a zero $\mathrm{N}$ retention in the body, which, when taking 
into account the stage of lactation (67 to 79 DIM), was considered justified.

The 2-yr data were analyzed according to a $4 \times 4$ Latin square design, with the mean effects of 4 cultivars measured over 4 periods with 3 plots (chemical constituents data) or cows (animal data) as replicates within each treatment, using the GLM procedure of SAS, version 8 (SAS Institute, Cary, NC). In 2002, 2 observations, and in 2003, 5 observations were omitted from analyses owing to illness of the cows. The chemical constituents were analyzed from both years with the following model:

$C C_{i j k}=\mu+Y_{i}+P_{j}\left(Y_{i}\right)+C_{k}+C_{k} \times Y_{i}+C_{k} \times P_{j}\left(Y_{i}\right)+e_{i j k}$,

where $C C_{i j k}$ is the chemical constituents trait, $\mu$ is the general mean, $Y_{i}$ is the year effect $(i=2002$ or 2003), $P_{j}\left(Y_{i}\right)$ is the period within the year effect $(j=1 \ldots 4)$, $C_{k}$ is the cultivar effect $(k=1 \ldots 4) ; C_{k} \times Y_{i}$ is the interaction between cultivar and year, $C_{k} \times P_{j}\left(Y_{i}\right)$ is the interaction between cultivar and period within the year, and $e_{i j k}$ is the residual error. With the following model,

$$
C C_{j k}=\mu+P_{j}+C_{k}+C_{k} \times P_{j}+e_{j k},
$$

cultivar effects were analyzed and standard errors of the difference were determined within each year.

The animal data were analyzed with the following model:

$$
A R_{i j k l}=\times+Y_{i}+P_{j}\left(Y_{i}\right)+C_{k}+A_{l}\left(Y_{i}\right)+C_{k} \times Y_{i}+e_{i j k l},
$$

where $A R_{i j k}$ is an animal response trait; $\mu$ is the general mean, $Y_{i}$ is the year effect ( $i=2002$ or 2003), $P_{j}\left(Y_{i}\right)$ is the period within the year effect $(j=1 \ldots 4), C_{k}$ is the cultivar effect $(k=1 \ldots 4), A_{l}\left(Y_{i}\right)$ is the animal within the year effect $(l=1 \ldots 12), C_{k} \times Y_{i}$ is the interaction between cultivar and year, and $e_{i j k l}$ is the residual error. Within each year, with the following model,

$$
A R_{j k l}=\mu+P_{j}+C_{k}+A_{l}+e_{j k l},
$$

cultivar effects were analyzed and standard errors of the difference were determined.

\section{RESULTS}

\section{Chemical Constituents in Herbage}

In both experiments, grass was in the vegetative stage with high proportions of leaf blade $(0.772 \pm 0.007$ in 2002 and $0.676 \pm 0.015$ in 2003 ) and low proportions of stem $(0.015 \pm 0.005$ in 2002 and $0.033 \pm 0.006$ in
2003). The DM content and constituents of the perennial ryegrass cultivars in the summer of 2002 and 2003 are presented in Table 1 . In both years, cultivars 1 and 4 had higher WSC concentrations ( 7 to $44 \mathrm{~g} / \mathrm{kg}$ of DM; $P$ $<0.001$ ) than cultivars 2 and 3 . In both years, cultivars 1 and 3 had higher CP concentrations ( 3 to $16 \mathrm{~g} / \mathrm{kg}$ of $\mathrm{DM} ; P<0.001)$ than cultivars 2 and 4 . In addition, the NDF concentration of cultivars 2 and 3 was always higher ( 2 to $23 \mathrm{~g} / \mathrm{kg}$ of DM; $P<0.001$ ) than cultivars 1 and 4 . The ranking of the cultivars for chemical composition was fairly consistent. In 2002, CP concentrations were lower than in $2003(>20 \mathrm{~g} / \mathrm{kg}$ of DM), whereas the opposite was found for WSC concentrations. Furthermore, the acid detergent lignin (ADL) concentrations in 2002 were lower than in $2003(>5 \mathrm{~g} / \mathrm{kg}$ of $\mathrm{DM})$.

\section{DMI, MY, and N Utilization}

In 2002 , cows consumed, on average, $2.4 \mathrm{~kg} \mathrm{DM} / \mathrm{d}$ more grass when grazing cultivar 4 with a high WSC concentration than when grazing cultivar 3 , with the lowest WSC concentration ( $P=0.03$; Table 2$)$. In 2003 , cows grazing cultivar 4 also had the highest herbage DMI, but differences in the other cultivars were smaller $(0.9$ to $1.4 \mathrm{~kg}$ of $\mathrm{DM} / \mathrm{d})$ and not significant $(P=0.53)$. In 2002, cows grazing cultivars 1 and 4 had a higher $(P<0.01) \mathrm{MY}$, milk fat production, and milk protein production compared with cultivar 3 . In 2003, there was only a small difference among cultivars in milk fat concentration $(P<0.01)$, whereas other production parameters were not affected $(P>0.05)$ by cultivar. In both years, the MUN concentration of cows grazing cultivar 3 was slightly higher $(\leq 16 \mathrm{mg} / \mathrm{L})$ than for the other cultivars, but only in 2003 did cultivar 3 have a higher $(P<0.05)$ MUN concentration than cultivars 2 and 4. In 2002, cows grazing cultivars 1 and 4 had a higher $\mathrm{N}$ intake $(P<0.05)$ and $\mathrm{N}$ excretion in milk $(P$ $<0.01$ ) than cows grazing cultivar 3 , but the efficiency of $\mathrm{N}$ utilization was not affected $(P=0.90)$. In 2003 , no effects of cultivar $(P \geq 0.18)$ on $\mathrm{N}$ intake, excretion, and utilization were found. The efficiency of $\mathrm{N}$ utilization was lower $(0.043 \mathrm{~g} / \mathrm{g})$ in 2003 than in 2002 , and this was associated with a higher MUN concentration (10 $\mathrm{mg} / \mathrm{L})$.

\section{DISCUSSION}

\section{Chemical Constituents in Herbage}

In both years, the largest difference among cultivars was found in the WSC concentration. As in the 2 previous years, when the herbage was cut for a stall-feeding experiment (Tas et al., 2006), cultivars 1 and 4 had higher WSC concentrations than did the other culti- 
Table 1. Dry matter content and chemical constituents in herbage, and in vitro organic matter digestibility (IVOMD) of 4 perennial ryegrass cultivars (cv.) during the summer in 2002 and 2003

\begin{tabular}{|c|c|c|c|c|c|c|c|c|c|c|c|c|c|c|c|}
\hline \multirow[b]{3}{*}{ Trait } & \multicolumn{10}{|c|}{ Year } & \multicolumn{5}{|c|}{ Level of significance ${ }^{2}$} \\
\hline & \multicolumn{4}{|c|}{2002} & \multirow[b]{2}{*}{$\mathrm{SED}^{1}$} & \multicolumn{4}{|c|}{2003} & \multirow[b]{2}{*}{ SED } & \multirow{2}{*}{$\begin{array}{l}\text { Year } \\
\text { (Y) }\end{array}$} & \multirow{2}{*}{$\begin{array}{l}\text { Period } \\
\text { (P) }\end{array}$} & \multirow{2}{*}{$\begin{array}{l}\text { Cultivar } \\
\text { (C) }\end{array}$} & \multirow[b]{2}{*}{$\mathrm{Y} \times \mathrm{C}$} & \multirow[b]{2}{*}{$\mathrm{P} \times \mathrm{C}$} \\
\hline & cv. 1 & cv. 2 & cv. 3 & cv. 4 & & cv. 1 & cv. 2 & cv. 3 & cv. 4 & & & & & & \\
\hline $\mathrm{DM}$ ( $\mathrm{g} / \mathrm{kg}$ of product) & 179 & 171 & 180 & 173 & 1.8 & 219 & 216 & 222 & 216 & 4.2 & **** & $* * *$ & $* * *$ & NS & NS \\
\hline Ash $(\mathrm{g} / \mathrm{kg}$ of $\mathrm{DM})$ & 94 & 96 & 102 & 97 & 1.3 & 80 & 83 & 86 & 85 & 1.1 & $* * *$ & **** & $* * *$ & NS & NS \\
\hline $\mathrm{NDF}(\mathrm{g} / \mathrm{kg}$ of $\mathrm{DM})$ & 458 & 481 & 477 & 475 & 3.3 & 470 & 490 & 484 & 474 & 3.7 & **** & $* * *$ & $* * *$ & $*$ & NS \\
\hline $\mathrm{ADL}^{3}$ (g/kg of $\left.\mathrm{DM}\right)$ & 26 & 26 & 28 & 24 & 0.4 & 32 & 32 & 33 & 30 & 0.6 & **** & $* * *$ & $* * *$ & NS & $* * *$ \\
\hline $\mathrm{CP}(\mathrm{g} / \mathrm{kg}$ of $\mathrm{DM})$ & 183 & 175 & 182 & 179 & 1.9 & 210 & 195 & 207 & 194 & 3.2 & **** & $* * *$ & $* * *$ & NS & NS \\
\hline WSC $(\mathrm{g} / \mathrm{kg}$ of $\mathrm{DM})$ & 149 & 132 & 110 & 144 & 2.7 & 114 & 107 & 87 & 131 & 3.9 & $* * *$ & $* * *$ & $* * *$ & $* * *$ & NS \\
\hline IVOMD (g/g) & 0.911 & 0.886 & 0.879 & 0.897 & 0.0028 & 0.856 & 0.833 & 0.841 & 0.854 & 0.0039 & $* * *$ & $* * *$ & $* * *$ & $*$ & $* * *$ \\
\hline
\end{tabular}

${ }^{1} \mathrm{SED}=$ Standard error of the difference.

${ }^{2}$ The significance of effects of year $(\mathrm{Y})$, period within year $(\mathrm{P})$, and cultivar $(\mathrm{C})$ and the interactions of year and period with cultivar $(\mathrm{Y} \times \mathrm{C}$ and $\mathrm{P} \times \mathrm{C}$, respectively) were tested. NS = not significant.

${ }^{3}$ Acid detergent lignin

$* P<0.05, * * P<0.01, * * * P<0.001$

Table 2. Herbage DMI, milk yield, milk composition, and $\mathrm{N}$ utilization in 12 dairy cows grazing 4 perennial ryegrass cultivars (cv.) in the summer of 2002 and 2003

\begin{tabular}{|c|c|c|c|c|c|c|c|c|c|c|c|c|c|c|c|}
\hline \multirow[b]{3}{*}{ Trait } & \multicolumn{10}{|c|}{ Year } & \multicolumn{5}{|c|}{ Level of significance $^{2}$} \\
\hline & \multicolumn{4}{|c|}{2002} & \multirow[b]{2}{*}{$\mathrm{SED}^{1}$} & \multicolumn{4}{|c|}{2003} & \multirow[b]{2}{*}{ SED } & \multirow{2}{*}{$\begin{array}{l}\text { Year } \\
(\mathrm{Y})\end{array}$} & \multirow{2}{*}{$\begin{array}{l}\text { Period } \\
\text { (P) }\end{array}$} & \multirow{2}{*}{$\begin{array}{l}\text { Animal } \\
\text { (A) }\end{array}$} & \multirow{2}{*}{$\begin{array}{l}\text { Cultivar } \\
\text { (C) }\end{array}$} & \multirow[b]{2}{*}{$\mathrm{Y} \times \mathrm{C}$} \\
\hline & cv. 1 & cv. 2 & cv. 3 & cv. 4 & & cv. 1 & cv. 2 & cv. 3 & cv. 4 & & & & & & \\
\hline Herbage DMI (kg/d) & 17.5 & 17.5 & 15.6 & 18.0 & 0.8 & 17.0 & 17.3 & 17.4 & 18.4 & 0.9 & NS & $* *$ & $*$ & $\dagger$ & NS \\
\hline Milk yield $(\mathrm{kg} / \mathrm{d})$ & 28.1 & 27.0 & 26.0 & 28.8 & 0.6 & 25.8 & 25.8 & 25.2 & 25.7 & 0.5 & $* * *$ & $* * *$ & $* * *$ & $* * *$ & $*$ \\
\hline Milk fat $(\mathrm{g} / \mathrm{d})$ & 1,093 & 1,047 & 1,021 & 1,106 & 21 & 996.7 & 974.6 & 932.4 & 933.1 & 28 & $* * *$ & $* * *$ & $* * *$ & $* *$ & * \\
\hline Milk protein $(\mathrm{g} / \mathrm{d})$ & 875 & 819 & 790 & 884 & 21 & 789.5 & 783.9 & 741.9 & 764.3 & 24 & $* * *$ & $* * *$ & $* * *$ & $* *$ & * \\
\hline Milk fat $(\mathrm{g} / \mathrm{kg})$ & 39.0 & 38.8 & 39.4 & 38.4 & 0.5 & 39.2 & 37.9 & 38.6 & 37.9 & 0.4 & $\dagger$ & $* * *$ & $* * *$ & $*$ & NS \\
\hline Milk protein $(\mathrm{g} / \mathrm{kg})$ & 31.3 & 30.4 & 30.4 & 30.8 & 0.3 & 31.0 & 30.5 & 30.7 & 30.7 & 0.3 & NS & $* * *$ & $* * *$ & $* *$ & NS \\
\hline MUN (mg/L) & 140 & 145 & 156 & 144 & 8 & 160 & 150 & 165 & 149 & 5 & $* *$ & $* * *$ & $* * *$ & * & NS \\
\hline $\mathrm{N}$ intake (g/d) & 569.7 & 539.3 & 506.0 & 573.8 & 25.6 & 623.0 & 604.7 & 632.0 & 623.0 & 30.3 & $* * *$ & $* * *$ & $\dagger$ & NS & NS \\
\hline $\mathrm{N}$ milk $(\mathrm{g} / \mathrm{d})$ & 137.1 & 128.2 & 123.7 & 139.0 & 3.3 & 123.7 & 122.9 & 116.9 & 123.7 & 3.8 & $* * *$ & $* * *$ & $* * *$ & $* * *$ & $*$ \\
\hline $\mathrm{N}$ utilization $(\mathrm{g} / \mathrm{g})$ & 0.246 & 0.241 & 0.245 & 0.246 & 0.01 & 0.203 & 0.209 & 0.190 & 0.203 & 0.01 & $* * *$ & $* * *$ & $* * *$ & NS & NS \\
\hline
\end{tabular}

$\infty \quad{ }^{1}$ SED $=$ Standard error of the difference.

Z $\quad{ }^{2}$ The significance of effects of year $(\mathrm{Y})$, period within year $(\mathrm{P})$, animal within year $(\mathrm{A})$ and cultivar $(\mathrm{C})$ and the interaction between year and cultivar $(\mathrm{Y} \times \mathrm{C})$ were tested. NS = not significant.

$\uparrow P<0.10, * P<0.05, * * P<0.01, * * * P<0.001$. 
vars. Our results confirm the conclusion of Humphreys (1989) that WSC concentration is a consistent trait, and it appears possible to select for cultivars with an elevated WSC concentration. When comparing cultivars differing in WSC concentration, Smith et al. (1998, 2002) reported altered composition and a decrease in $\mathrm{NDF}$, and suggested that the additional WSC was compensated for by a reduction in NDF rather than by a reduction in CP. In the present study, the elevated WSC concentrations in cultivars 1 and 4 were associated with reduced NDF (cultivar 1) or ADL (cultivar 4) concentrations, whereas CP concentrations were hardly affected. This was also found in the previous experiment (Tas et al., 2006) and in the studies conducted by Miller et al. (2001) and Lee et al. (2002). However, in the latter 2 studies the mean NDF concentrations were relatively high ( $>540 \mathrm{~g} / \mathrm{kg}$ of DM) and the mean CP concentrations were low (92 to $107 \mathrm{~g} / \mathrm{kg}$ of $\mathrm{DM}$ ) in comparison with the present study. Moreover, the difference in NDF concentration and in vitro organic matter digestibility between cultivars was larger in these studies compared with the present study. The higher $\mathrm{N}$ fertilization level in 2003 compared with 2002 resulted in a higher CP and a lower WSC concentration, whereas the NDF concentration was almost unaffected, in agreement with the review by Peyraud and Astigaragga (1998). The higher ADL concentration in the second year of this experiment was also observed in the stall-feeding experiment (Tas et al., 2006), and this may be related to the $1 \mathrm{yr}$ older sward and the longer regrowth period in 2003.

\section{DMI, MY, and N Utilization}

Herbage DMI in this study was positively related to sward height, DM yield, and green leaf mass, and negatively related to crown rust infestation (Smit et al., 2005a). Cultivars with an elevated WSC concentration showed a higher DMI in 2002, but not in 2003. The latter was in agreement with the absence of DMI differences among cultivars differing in WSC concentration in the stall-feeding experiment (Tas et al., 2005), but was in contrast to the positive relationship between the WSC concentration and DMI in early-lactating (Moorby et al., 2006) and late-lactating dairy cows (Miller et al., 2001). However, in these studies the higher WSC concentration was confounded with a lower NDF concentration (41 and $83 \mathrm{~g} / \mathrm{kg}$ of DM) and a higher DM digestibility (0.07 and $0.03 \mathrm{~g} / \mathrm{g}$; Miller et al., 2001; Moorby et al., 2006). The DMI is the main determinant of MY, and this largely explains the differences observed among cultivars in MY, milk fat, and protein yield in 2002. The small differences in herbage chemical constituents were not expected to affect milk composi- tion. In both years, no differences were found in $\mathrm{N}$ intake and $\mathrm{N}$ utilization among cultivars. In contrast, Miller et al. (2001) found, with similar N intakes, a higher $\mathrm{N}$ utilization in late-lactating cows fed a cultivar with an elevated WSC concentration. However, a similar $\mathrm{N}$ utilization in early-lactating cows was found when comparing these cultivars (Moorby et al., 2006). Theoretically, the increase in energy available for rumen microbes because of the shift from structural (NDF) to nonstructural (WSC) carbohydrates may result in an improved ratio of rapidly available energy to $\mathrm{N}$ required for rumen microbial growth. This shift may therefore reduce rumen ammonia production and urinary urea excretion, as shown in simulations by Kebreab et al. (2002). In agreement, in vitro measurements indicated a higher efficiency of microbial protein synthesis by the addition of sugars to ryegrass (Lee et al., 2003). However, the increased dilution rate at higher WSC concentrations in these in vitro systems may have contributed to this rise in microbial efficiency, since the fractional dilution rate is one of the major determinants of microbial efficiency (Dijkstra et al., 2002). In steers fed ryegrass cultivars differing in WSC concentration ( $83 \mathrm{~g} / \mathrm{kg}$ of DM), the in vivo efficiency of microbial protein synthesis and flow of $\mathrm{N}$ to the duodenum as a proportion of $\mathrm{N}$ intake were not different (Lee et al., 2002). Moreover, supplementing grazing dairy cows with nonstructural carbohydrates at the time of grazing, or $4 \mathrm{~h}$ after grazing, did not affect the mean ruminal-NH3, blood urea $\mathrm{N}$ concentration, and $\mathrm{N}$ excretion in milk (Kolver et al., 1998). Moreover, in most cases the supply of ME rather than the supply of MP is the first limiting factor for MY of dairy cows grazing highquality grass (Kolver and Muller, 1998; Peyraud and Delaby, 2001). At the concentrations of CP in grass $(\geq 175 \mathrm{~g} / \mathrm{kg}$ of $\mathrm{DM})$ and MY $(<29 \mathrm{~kg} / \mathrm{d})$ in the present study, a potential marginal increase in microbial protein synthesis, and hence MP supply, may have been catabolized rather than used for milk protein synthesis. Comparison of cultivars at low CP concentrations $(<110$ $\mathrm{g} / \mathrm{kg}$ of DM) showed that MP was limiting, and this may explain the higher milk protein yield in dairy cows fed the cultivar with a higher WSC concentration (Miller et al., 2001; Moorby et al., 2006). However, N utilization of this cultivar was higher only in late lactation (Miller et al., 2001) and not in early lactation (Moorby et al., 2006). This supports the absence of an effect of an elevated WSC concentration in ryegrass cultivars with moderate to high CP concentrations ( $\geq 175 \mathrm{~g} / \mathrm{kg}$ of DM) on $\mathrm{N}$ utilization in the present study, and confirms our previous findings in stall-feeding the ryegrass cultivars, with the exception of a higher $\mathrm{N}$ utilization of cultivar 1 than of cultivar 3 in 2000 (Tas et al., 2006). 
The MUN concentration is an indicator of the excess $\mathrm{N}$ in the rumen for microbial fermentation or excess AA in the intermediate metabolism in the animal, or both (Lobley et al., 2000). In both years, cultivars 1 and 3 had a higher CP concentration than cultivars 2 and 4, but this was associated only with a higher MUN concentration in 2003. The higher WSC concentration of cultivar 1 than of cultivar 3 may have balanced the supply of $\mathrm{N}$ in 2002 at the lower CP concentration, but not in 2003 at the higher CP concentration. The lower $\mathrm{N}$ utilization in 2003 compared with 2002 was, to a larger extent, related to the lower MY, and hence milk protein yield, than were the higher CP and lower WSC concentrations in the herbage in 2003 than in 2002. At the relatively high $\mathrm{CP}$ concentration in the herbage in a stall-feeding experiment (Tas et al., 2006) and in the present study, cultivars with an elevated WSC concentration did not result in a consistently higher $\mathrm{N}$ utilization in dairy cows.

\section{CONCLUSIONS}

Comparing the herbage chemical constituents of 4 diploid perennial ryegrass cultivars, the largest difference was found in WSC concentration. These results confirmed earlier observed differences showing that an elevated WSC concentration is a consistent cultivar characteristic. At relatively high $\mathrm{CP}$ concentrations and with small differences among cultivars in NDF concentration, however, cultivars with an elevated WSC concentration did not consistently result in higher herbage DMI, MY, or milk $\mathrm{N}$ yield or in a higher $\mathrm{N}$ utilization in grazing or stall-fed dairy cows.

\section{ACKNOWLEDGMENTS}

The authors would like to thank the personnel of the experimental farms De Ossekampen and Unifarm, the Animal Nutrition laboratory, and graduate students for their assistance. The financial support from the Ministry of Economic Affairs (Senter), The Hague, The Netherlands, and Barenbrug Holland BV, Oosterhout, The Netherlands, is greatly acknowledged.

\section{REFERENCES}

Dijkstra, J., J. A. N. Mills, and J. France. 2002. The role of dynamic modelling in understanding the microbial contribution to rumen function. Nutr. Res. Rev. 15:67-90.

Humphreys, M. O. 1989. Water-soluble carbohydrates in perennial ryegrass breeding. II. Cultivar and hybrid progeny performance in cut plots. Grass Forage Sci. 44:237-244.

International Organization for Standardization (ISO). 1999. ISO 9622: Whole milk-Determination of milkfat, protein and lactose content-Guidance on the operation of mid-infrared instruments. ISO, Geneva, Switzerland.

International Organization for Standardization (ISO). 2004. ISO 14637: Milk-Determination of urea content_Enzymatic method using difference in $\mathrm{pH}$ (Reference method). ISO, Geneva, Switzerland.

Kebreab, E., J. France, J. A. N. Mills, R. A. Allison, and J. Dijkstra. 2002. A dynamic model of $\mathrm{N}$ metabolism in the lactating dairy cow and an assessment of impact of $\mathrm{N}$ excretion on the environment. J. Anim. Sci. 80:248-259.

Kolver, E. S., and L. D. Muller. 1998. Performance and nutrient intake of high producing Holstein cows consuming pasture or a total mixed ration. J. Dairy Sci. 81:1403-1411.

Kolver, E. S., L. D. Muller, G. A. Varga, and T. J. Cassidy. 1998. Synchronization of ruminal degradation of supplemental carbohydrate with pasture nitrogen in lactating dairy cows. J. Dairy Sci. 81:2017-2028.

Lee, M. R. F., L. J. Harris, J. M. Moorby, M. O. Humphreys, M. K. Theodorou, J. C. MacRae, and N. D. Scollan. 2002. Rumen metabolism and nitrogen flow to the small intestine in steers offered Lolium perenne containing different levels of water-soluble carbohydrate. Anim. Sci. 74:587-596.

Lee, M. R. F., R. J. Merry, D. R. Davies, J. M. Moorby, M. O. Humphreys, M. K. Theodorou, J. C. MacRae, and N. D. Scollan. 2003. Effect of increasing availability of water-soluble carbohydrates on in vitro rumen fermentation. Anim. Feed Sci. Technol. 104:59-70.

Lobley, G. E., G. D. Milano, and J. G. Van der Walt. 2000. The liver: Integrator of nitrogen metabolism. Pages 149-168 in Ruminant Physiology: Digestion, Metabolism, Growth and Reproduction. P. B. Cronj, ed. CAB International, Wallingford, UK.

Mayes, R. W., C. S. Lamb, and P. M. Colgrove. 1986. The use of dosed and herbage n-alkanes as markers for determination of herbage intake. J. Agric. Sci. 107:161-170.

Miller, L. A., J. M. Moorby, D. R. Davies, M. O. Humphreys, N. D. Scollan, J. C. MacRae, and M. K. Theodorou. 2001. Increased concentration of water-soluble carbohydrate in perennial ryegrass (Lolium perenne): Milk production from late-lactation dairy cows. Grass Forage Sci. 56:383-394.

Moorby, J. M., R. T. Evans, N. D. Scollan, J. C. MacRae, and M. K. Theodorou. 2006. Increased concentration of water-soluble carbohydrate in perennial ryegrass (Lolium perenne L.). Evaluation in dairy cows in early lactation. Grass Forage Sci. 61:52-59.

Peyraud, J. L., and L. Astigaragga. 1998. Review of the effect of nitrogen fertilization on the chemical composition, intake, digestion and nutritive value of fresh herbage: Consequences on animal nutrition and N balance. Anim. Feed Sci. Technol. 72:235-259.

Peyraud, J. L., and L. Delaby. 2001. Ideal concentrate feeds for grazing dairy cows-Responses to supplementation in interaction with grazing management and grass quality. Pages 203-220 in Recent Advances in Animal Nutrition. P. C. Garnsworthy and J. Wiseman, ed. Nottingham Univ. Press, Nottingham, UK.

Peyraud, J. L., R. Mosquera-Losado, and L. Delaby. 2004. Challenges and tools to develop efficient dairy systems based on grazing: how to meet animal performance and grazing management. Pages 373-384 in Proc. XXth Europ. Grassl. Fed.: Land Use Systems in Grassland Dominated Regions. Luzern, Switzerland. VDF, Zürich, Switzerland.

Smith, K. F., R. J. Simpson, R. N. Oram, K. F. Lowe, K. B. Kelly, P. M. Evans, and M. O. Humphreys. 1998. Seasonal variation in the herbage yield and nutritive value of perennial ryegrass (Lolium perenne L.) cultivars with high or normal herbage water-soluble carbohydrate concentrations grown in three contrasting Australian dairy environments. Aust. J. Exper. Agric. 38:821-830.

Smith, K. F., R. A. Culvenor, M. O. Humphreys, and R. J. Simpson. 2002. Growth and carbon partitioning in perennial ryegrass $(\mathrm{Lol}$ ium perenne) cultivars selected for high water-soluble carbohydrate concentrations. J. Agric. Sci. 138:375-385.

Smit, H. J., B. M. Tas, H. Z. Taweel, S. Tamminga, and A. Elgersma. 2005a. Effects of perennial ryegrass (Lolium perenne L.) cultivars on herbage production, nutritional quality and herbage intake of grazing dairy cows. Grass Forage Sci. 60:297-309.

Smit, H. J., H. Z. Taweel, B. M. Tas, S. Tamminga, and A. Elgersma. 2005b. Comparison of techniques for estimating herbage intake of grazing dairy cows. J. Dairy Sci. 88:1827-1836.

Tas, B. M., H. Z. Taweel, H. J. Smit, A. Elgersma, J. Dijkstra, and S. Tamminga. 2005. Effects of perennial ryegrass cultivars on 
intake, digestibility and milk yield in dairy cows. J. Dairy Sci. 88:3240-3248.

Tas, B. M., H. Z. Taweel, H. J. Smit, A. Elgersma, J. Dijkstra, and S. Tamminga. 2006. Utilisation of $\mathrm{N}$ in perennial ryegrass cultivars by stall-fed lactating dairy cows. Livest. Sci. 100:159-168.

Taweel, H. Z., B. M. Tas, H. J. Smit, A. Elgersma, J. Dijkstra, and S. Tamminga. 2005. Improving the quality of perennial ryegrass (Lolium perenne L.) for dairy cows by selecting for fast clearing and/or degradable neutral detergent fiber. Livest. Prod. Sci. 96:239-248

van Vuuren, A. M. 1993. Digestion and nitrogen metabolism of grass fed dairy cows. PhD Thesis, Wageningen Agricultural University, Wageningen, The Netherlands.

Veerkamp, R. F., G. Simm, and J. D. Oldham. 1994. Effects of interaction between genotype and feeding system on milk production, feed intake, efficiency and body tissue mobilization in dairy cows. Livest. Prod. Sci. 39:229-241. 